\title{
FBP1 wt Allele
}

National Cancer Institute

\section{Source}

National Cancer Institute. FBP1 wt Allele. NCI Thesaurus. Code C117101.

Human FBP1 wild-type allele is located in the vicinity of $9 q 22.3$ and is approximately $37 \mathrm{~kb}$ in length. This allele, which encodes fructose-1,6-bisphosphatase 1 protein, is involved in gluconeogenesis. Mutation of the gene is associated with fructose-1,6-bisphosphatase deficiency, which can cause life-threatening episodes of hypoglycemia and metabolic acidosis. 